\title{
Constraints on the tectonic evolution of the Central European Basin System revealed by seismic reflection profiles from Northern Germany
}

\section{S. Mazur ${ }^{\star} \&$ M. Scheck-Wenderoth}

GeoForschungsZentrum Potsdam, Telegrafenberg, D-14473 Potsdam, Germany.

* Corresponding author. Present address: S. Mazur, Institute of Geological Sciences, University of Wroclaw, Pl. M. Borna 9, 50-204 Wroclaw, Poland. Email: smazur@ing.uni.wroc.pl

Manuscript received: October 2004; accepted: October 2005

\begin{abstract}
A selection of reflection-seismic lines from the southern part of the Central European Basin System and its southern margin were used to establish the spectrum of extensional and compressional deformation structures and to calibrate the timing of these events. The lines are arranged in a N-S and an E-W transect running across the Pompeckj Block and the Lower Saxony Basin in Northern Germany. The structural record provided by the seismic data points to an interplay between far-field horizontal stresses and vertical movements of the basin floor, the latter only weakly correlated with the development of seismic-scale tectonic structures. A detailed seismo-stratigraphic analysis indicates that Late Triassic-Jurassic extension has been the principal control on the structure of the E-W profile, whereas the N-S profile is dominated by compressional structures associated with Late Cretaceous inversion. Overprint effects of extension and inversion tectonics can be classified among a few distinct tectonic events accompanied by movements of the Upper Permian salt: firstly, an episode of subsidence and diapiric rise in the Keuper; secondly, a clear Jurassic-to-Early Cretaceous extension recorded by normal faulting and differential subsidence. The latter was interrupted by a major episode of Late Jurassic uplift. Thirdly, a Late Cretaceous-Early Paleogene basin inversion was associated with approximately N-S compression; and fourthly, recurring extension during the Cenozoic associated with diapiric rise and collapse. The Mesozoic extension is expressed in a number of normal faults that were most active during the Early Cretaceous localised subsidence within the Lower Saxony Basin. The deformation associated with the Late Cretaceous inversion was partly decoupled along the salt. The compressional deformation at the southern margin of the basin was thick-skinned in style, characterized by folding and faulting of the Mesozoic sedimentary fill and pre-Zechstein strata. Further north, towards the centre of the basin, folding and reverse faulting were mostly concentrated above the salt. The tectonic evolution of the investigated area suggests the presence of a zone of crustal weakness along the SW margin of the Central European Basin System which allowed strain localization in response to a favourable oriented stress field.
\end{abstract}

Keywords: basin inversion, deformation decoupling, Elbe Fault System, Permo-Mesozoic, salt

\section{Introduction}

The post-rift deformation history of the Permo-Mesozoic Basins of NW and Central Europe in response to varying regional stresses has been the subject of a long-lasting debate. The complex basin system experienced multiple deformation phases resulting in the development of new crustal discontinuities and repeated reactivation of pre-existing ones (Ziegler et al., 1995). The basins evolved over a large time span from rifting during the Late Carboniferous and Permian, rifting in the Late Triassic to renewed Jurassic to Early Cretaceous rifting and subsidence, Late Cretaceous to Paleogene inversion and, finally, Cenozoic subsidence and sedimentation. Since the PermoMesozoic basins are mostly concealed beneath a thick Cenozoic cover, their investigation predominantly relies on borehole and seismic data. This paper presents newly released seismic data from Northern Germany which can constrain results of recent structural modelling (e.g. Scheck \& Bayer, 1999; Stephenson 


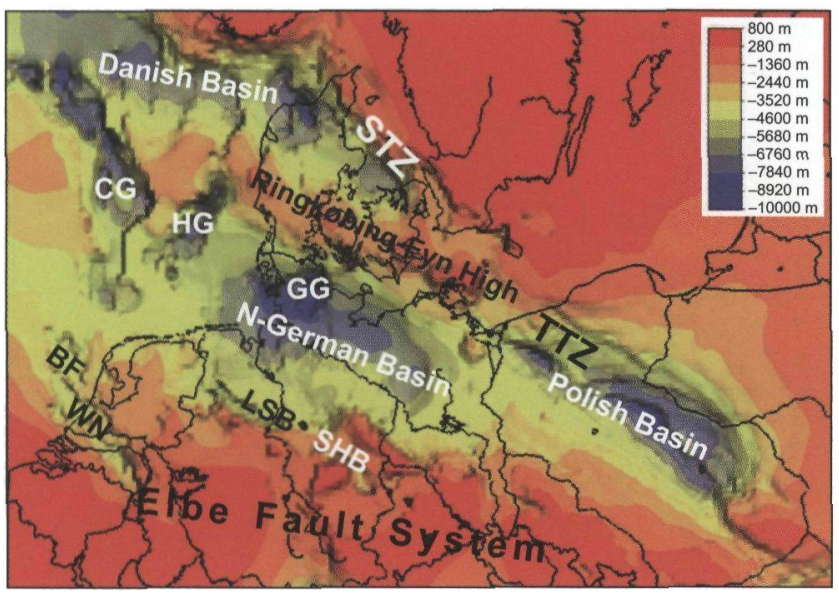

CG: Central Graben STZ: Sorgenfrei-Tornquist Zone LSB: Lower Saxony Basin HG: Horn Graben TTZ: Teisseyre-Tornquist Zone SHB: Subhercynian Basin GG: Glückstadt Graben WN: West Netherlands Basin BF: Broad Fourteens Basin a.

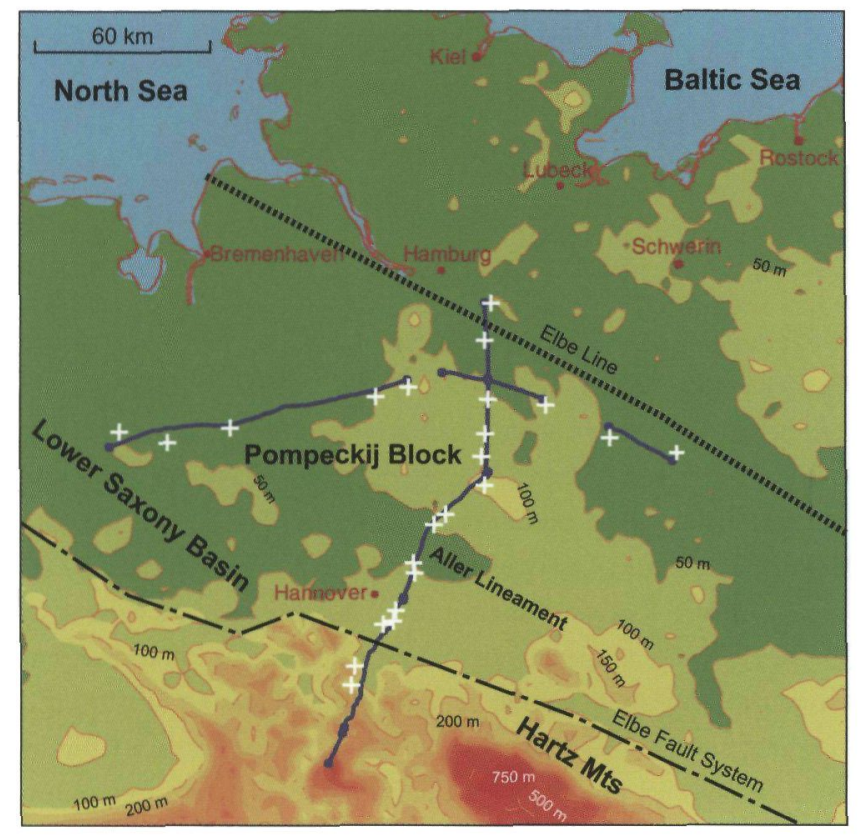

b.

Fig. 1. Location of the study area in the regional tectonic framework of NW Europe (a) and geographic position of the investigated seismic lines (heavy blue lines) together with distribution of wells (white crosses) used for the calibration of stratigraphy (b). Map (a) shows depth of the base Permian. Topographic contour lines in map (b) are spread every $50 \mathrm{~m}$.

et al., 2003; Scheck et al., 2003a,b) and help to establish the link between model predictions and structural observations.

Our study is focused on the Central European Basin System (CEBS), a continental rift system related to the Permo-Mesozoic break up of Pangea, which extends from the North Sea to western Poland (Fig. 1). The understanding of the structural configuration and evolution of the CEBS has been greatly advanced due to intense exploration activity carried out by the petroleum industry. We use a number of seismic lines from the southern margin and centre of the CEBS to make up a N-S and an E-W transect running across the Pompeckj Block and the Lower Saxony Basin in Northern Germany, which are separated by the WNW-ESE trending Aller Lineament (Fig. 1b). The lines are tied to about 20 wells published in the Tectonic Atlas of North-West Germany and the German sector of the North Sea (Baldschuhn et al., 2001).

Our main goal in this study was to investigate the response of the sedimentary fill to far-field horizontal stress and deep seated processes in the underlying crust. The main tectonic phenomena addressed in the paper comprise: (1) shallow crustal expression of Triassic to Early Cretaceous extension and transtension related to rifting in the North Sea and North Atlantic, (2) relationship between the Late Jurassic syn-extensional uplift and the tectonic regime controlling basin architecture, (3) basin inversion in response to build-up of intra-plate horizontal compressional stress induced by the early stages of Alpine collision.

\section{Outline of structural development}

The CEBS extends over a large area from the southern North Sea across Denmark, the Netherlands and Northern Germany to Poland (Fig. 1a) and is confined between the TeisseyreTornquist and Tornquist-Sorgenfrei zones in the NE and outcrops of the Variscan fold belt in the SW. The Variscides are separated from the CEBS by a zone of en echelon faults collectively referred to as the Elbe Fault System (Scheck et al., 2002). The CEBS roughly corresponds to the post-Variscan Northern and Southern Permian basins of Ziegler (1990) comprising a number of sub-basins the largest of which are: (1) the Norwegian-Danish Basin, (2) the North German Basin and (3) the Polish Basin (Fig. 1a). The total thickness of Permian to Cenozoic sediments locally attains $8-10 \mathrm{~km}$ within the N-S trending grabens.

Initial Early Permian rifting in the area of the CEBS was accompanied by widespread volcanic activity followed by postrift thermal subsidence with deposition of Lower Permian Rotliegend clastics and Upper Permian Zechstein salt. The predominant configuration of the WNW-ESE elongated Permian depocentres was presumably controlled by the orientation of the pre-existing Variscan structural grain partly reactivated during the Stephanian to Early Permian phase of dextral wrenching (Betz et al., 1987; Ziegler, 1990). The calculated basement subsidence for the North German Basin, based on seismic section restoration (Kossow \& Krawczyk, 2002) as well as from subsidence analysis (Scheck and Bayer, 1999), shows strong subsidence at the beginning of basin formation in Permo-Triassic times when more than $3000 \mathrm{~m}$ of compacted sediments were deposited in the basin centre. Continued differential subsidence during Triassic to Middle Jurassic times was related to a new stress regime associated with the onset of Atlantic break-up between America and Europe. A NNE-SSW trending system of grabens and troughs, including the Central, Horn and Glückstadt grabens, was established in response to 
approximately E-W extension (Betz et al., 1987; Scheck \& Bayer, 1999). Also the regional mid-Buntsandstein Hardegsen unconformity is related to this phase of structuration (e.g. Geluk et al., 1996; Kockel, 2002). The newly formed depressions, with locally strong subsidence from the Keuper onward, overprinted the Permian basin architecture perpendicularly. From the Jurassic onwards, the rate of basement subsidence decreased in all parts of the North German Basin (Kossow \& Krawczyk, 2002). During the Late Jurassic, the area was uplifted and a regional erosional unconformity developed (e.g. Betz et al., 1987). Soon afterwards, starting from the latest Jurassic/earliest Cretaceous, a dextral transtensional regime was established (Betz et al., 1987; Scheck \& Bayer, 1999) in connection with E-W extension and rifting along the Central Graben System. There, the earlier NW-SE Hercynian structural trend was reactivated causing considerable strike-slip displacements and the formation of en-echelon sub-basins as the Sole Pit, the Broad Fourteens, the West Netherlands, the Lower Saxony and the Subhercynian basins arranged along the SW margin of the CEBS. In the Late Cretaceous and Paleogene the CEBS was affected by a number of inversion phases the most important of which, the sub-Hercynian and Laramide phases, took place in the Senonian and mid-Paleocene, respectively. The morphology, origin and age of inversion structures in Northern Germany was recently discussed by Kockel (2003). Early Tertiary compressional deformation was followed by resumed Cenozoic subsidence, possibly related to the accelerated subsidence in the central part of the North Sea (Scheck \& Bayer, 1999). In addition, the tectonic evolution of the CEBS from the Triassic onward was significantly influenced by salt mobilisation (Jaritz, 1987; Scheck et al., 2003 a,b).

\section{Seismic data}

In this study, we used eight seismic reflection lines that were acquired in the years 1974 - 1985 (Fig. 1b). In addition to the standard seismic processing sequence, a coherency filtering has been applied to these data at the Institute of Geophysics, Technical University of Clausthal. The combined profiles provide one N-S and one E-W transect, both of which have been tied to well profiles (Baldschuhn et al., 2001) to correlate the stratigraphic units with the seismic data. Due to the nonavailability of well log information, interval velocities were derived from stacking velocities at the well locations in order to convert depth positions of stratigraphic horizons into time. An overview of the transects is given in Fig. 2 and details are shown in close-ups in Figs 3 - 10.

\section{Pre-Zechstein}

The base Zechstein defines a well-pronounced single or double reflection over the majority of the investigated transects. In places it is underlain by a relatively reflective sequence up to
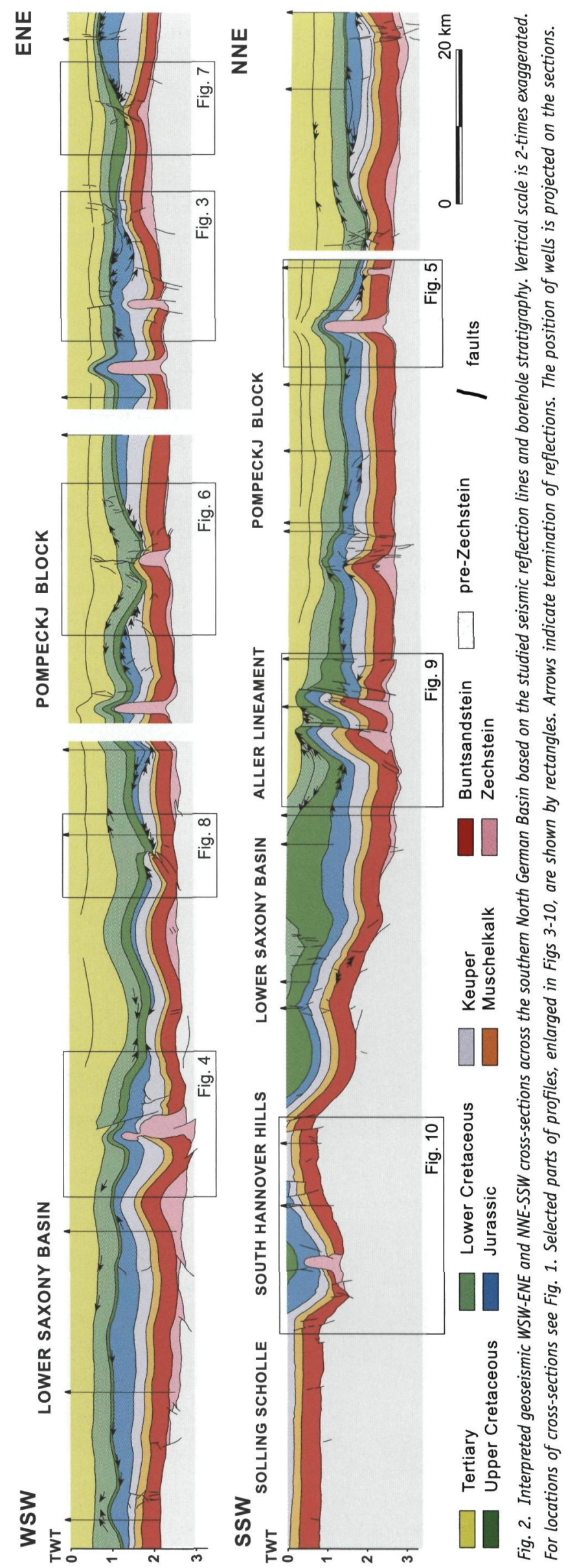
$0.2-0.3 \mathrm{~s}$ TWT thick, probably corresponding to Rotliegend sediments. More often, however, the seismic structure of the pre-Zechstein strata is poorly visible. In the western part of the $\mathrm{E}-\mathrm{W}$ transect, the base Zechstein is disrupted by a number of minor SW-dipping faults with offsets in the range of $0.1-0.2 \mathrm{~s}$ TWT. Other than these faults, the base Zechstein shows little structuration (Fig. 2). Only south of Hannover, the base Zechstein is uplifted by almost $2 \mathrm{~s}$ TWT and folded together with the underlying strata. And also, in the area of the South Hannover Hills, the base Zechstein is faulted.

\section{Zechstein}

The Zechstein evaporites usually correspond to a mostly transparent and discontinuous succession with repeatedly and rapidly changing thickness resulting from salt mobilisation. Salt pillows are observed in the core of several anticlines in the Pompeckj Block and the Lower Saxony Basin and within the anticlines occurring at the Aller Lineament. Locally, sharp terminations of reflections can be seen against the transparent diapirs of poorly imaged shape. Along the majority of the investigated transects, sections with salt structures alternate with those apparently devoid of the transparent Zechstein succession. At the SW margin of the CEBS south of Hannover, poorly reflective Zechstein evaporites are practically missing.

\section{Buntsandstein and Muschelkalk}

Both the Buntsandstein and Muschelkalk are represented by a set of parallel and characteristic reflections traceable over long distances. The thickness of this reflective succession, with high velocity contrasts, is very uniform along the investigated seismic lines and corresponds to ca $0.45 \mathrm{~s}$ TWT and $0.2 \mathrm{~s}$ TWT for the Buntsandstein and Muschelkalk respectively. Only at the SW margin of the CEBS, in the area of the South Hannover Hills, some variations in thickness can be observed (Fig. 2). Furthermore, the Buntsandstein beneath the Lower Saxony Basin south of Hannover locally comprises a sequence of converging reflections truncated by the base Muschelkalk, possibly imaging the Hardegsen unconformity. In places, a characteristic double reflection corresponding to the base Muschelkalk is visible.

\section{Keuper}

The base Keuper is parallel to the underlying Muschelkalk and Buntsandstein and can be traced over long distances between salt structures although locally it is represented by a distinctive reflection. The overall reflectivity of the Keuper is good and its thickness varies between 0 and $0.5 \mathrm{~s}$ TWT (Fig. 2). Changes of thickness can be attributed to depositional thickening and thinning as well as to erosional truncation by the base Jurassic
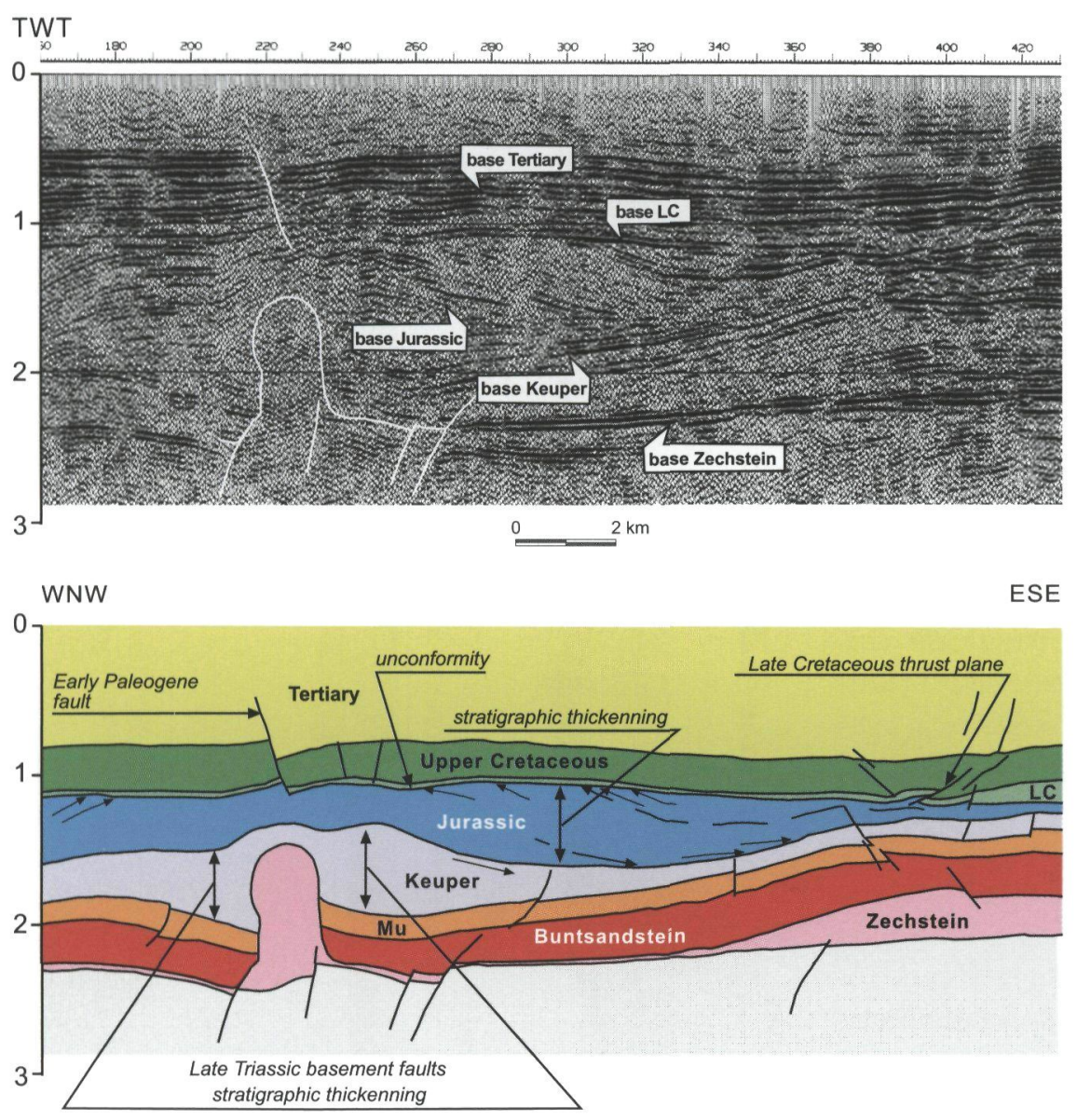

Fig. 3. Close-up of the WNW-ESE seismic transect across the eastern part of the Pompeckj Block illustrating (1) salt diapirism accompanied by depositional thickening in the rim synclines; note that the normal fault in the cover is offset with respect to the basement fault, (2) depositional thickening of the Jurassic due to continued salt mobility, (3) Early Paleogene inversion tectonics manifested by reverse reactivation of the Keuper-Jurassic normal fault and newly formed faults. LC Lower Cretaceous; Mu - Muschelkalk. 

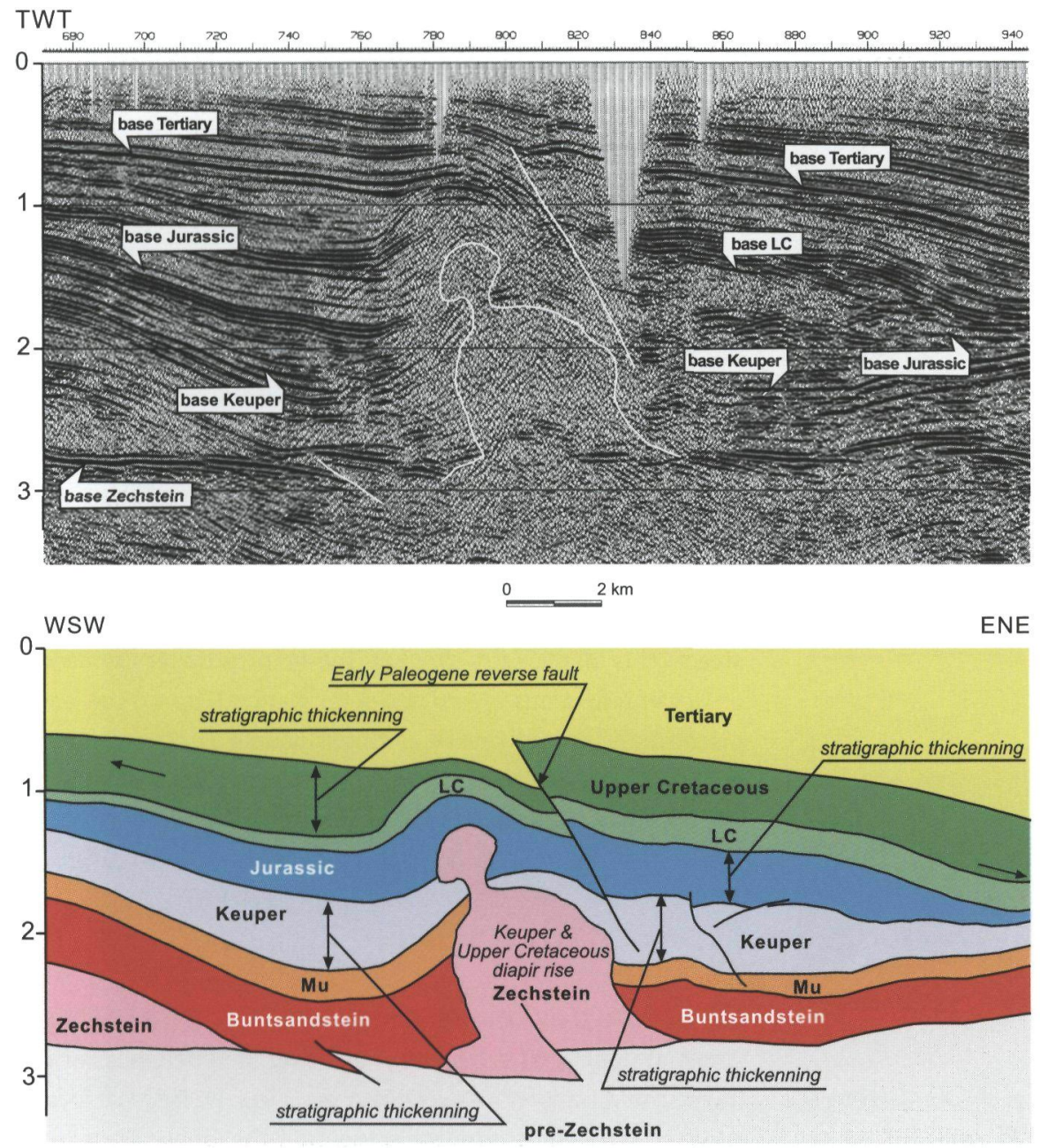

Fig. 4. Close-up of the WSW-ENE seismic transect across the northern part of the Lower Saxony Basin illustrating effects of Keuper, Jurassic and Late Cretaceous salt diapir rise accompanied by stratigraphic thickening in the rim synclines. Early Paleogene inversion tectonics led to reverse faulting with considerable uplift of the hanging wall. $L C$ Lower Cretaceous; Mu - Muschelkalk.

or the base Cretaceous unconformity. Depositional thickening of the Keuper succession in rim synclines associated with salt diapirs, is best visible on the $\mathrm{E}-\mathrm{W}$ transect (Figs 3,4). In one case, an asymmetric rim syncline attains greater thickness in the hanging wall of a normal fault, which is partly masked by a salt diapir, as can be seen in the close-up of Fig. 3. As evident in Fig. 2, generally greater variation of the Keuper thickness is noted in the area of the Pompeckj Block where the Keuper reflections occasionally show onlap terminations against the top Muschelkalk (Fig. 5). On the other hand, at the northern end of the N-S transect and on the limbs of the salt anticline north of the Aller Lineament (Fig. 2), the Keuper reflections parallel to the top Muschelkalk are erosionally truncated by the base Jurassic unconformity.

\section{Jurassic}

The base Jurassic is visible only locally as a conspicuous reflection, whereas more often the Keuper and Jurassic form fairly continuous successions of comparable seismic characteristics. It is only in the Lower Saxony Basin (western part of the E-W transect in Fig. 2), that the Jurassic displays a more transparent seismic image than the underlying Keuper. Only in a few cases the base Jurassic is an unconformity, as suggested by erosional truncation of the Keuper reflections (Fig. 5). In contrast, the reflection interpreted as the top Jurassic / base Cretaceous represents a regional unconformity, truncating the Jurassic and locally also older units (Fig. 2). Thus, the rapid thickness changes of the Jurassic succession from 0 to $0.6 \mathrm{~s}$ TWT seem to result rather from erosional truncation than from a really variable rates of deposition. In addition, the Jurassic also thickens into rim synclines, which is best shown on the $\mathrm{E}-\mathrm{W}$ transect (Fig. 2). Fig. 3 illustrates a locally thickened Jurassic succession within a salt syncline between a diapir and salt pillow.

\section{Lower Cretaceous}

The base Cretaceous represents a regional unconformity and is almost always evident as a conspicuous single or double reflection. In Fig. 6, the base Cretaceous reflection truncates the entire Jurassic and Keuper down to the Muschelkalk. Sharp terminations of reflections against the base Cretaceous clearly delineate the position of the unconformity. Fig. 2 shows that the Lower Cretaceous is very thin along the E-W transect and in the northern part of the N-S transect. In contrast, the Lower Cretaceous is up to $1.1 \mathrm{~s}$ TWT-thick in the Lower Saxony 


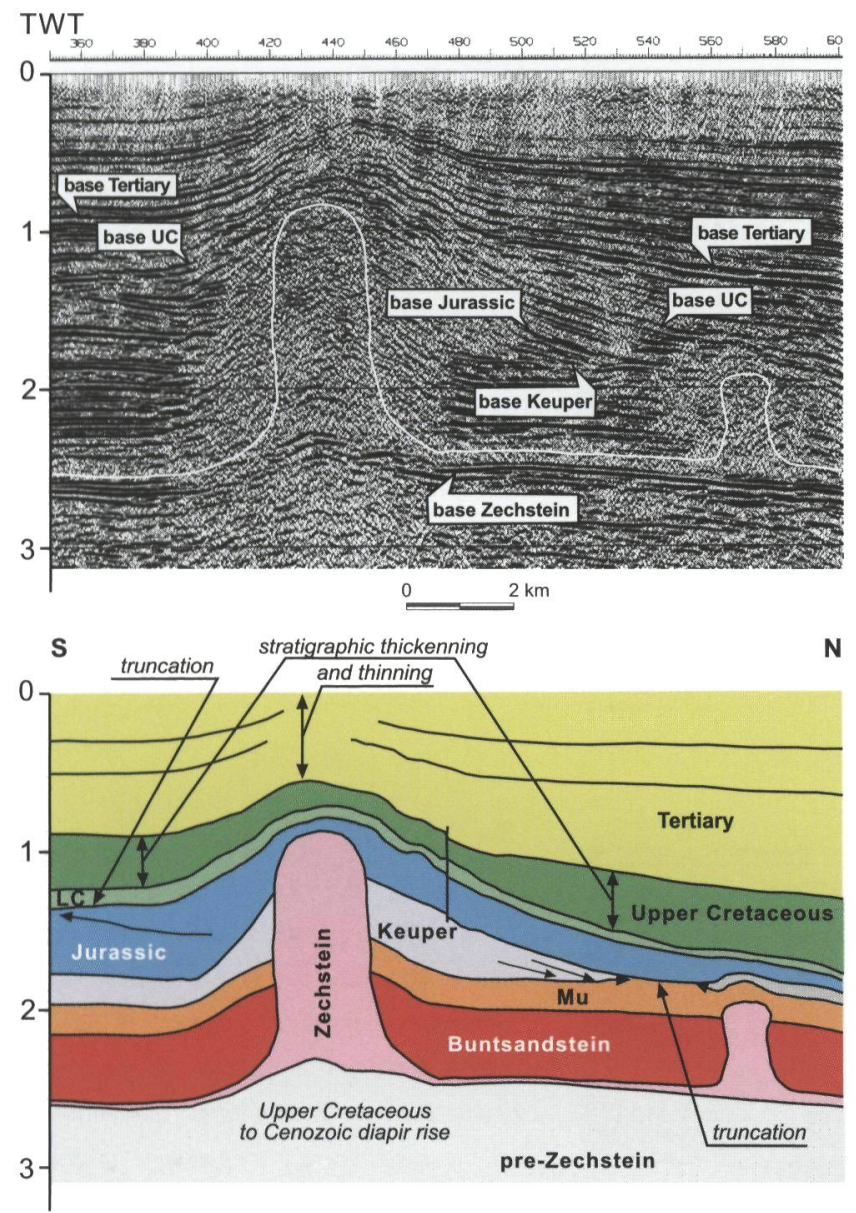

Fig. 5. Close-up of the N-S seismic transect across the Pompeckj Block illustrating onlap termination of the Keuper reflections against the top Muschelkalk. Locally the base Jurassic unconformity truncates down to the Muschelkalk. Continued diapirism during the Late Cretaceous and Cenozoic is indicated by stratigraphic thickening of the rim synclines. LC - Lower Cretaceous; Mu - Muschelkalk.

Basin south of Hannover, where it is represented by a uniform, highly reflective succession. At the northern margin of the Lower Saxony Basin, the Lower Cretaceous reflections show onlap terminations against the top Jurassic. This is especially evident within the syncline that adjoins the Aller Lineament to the south. Near the eastern termination of the E-W transect, the thickness of the Lower Cretaceous is locally increasing within an asymmetric lensoidal body (Fig. 2). Its shape suggests an origin through syn-sedimentary subsidence enhanced by the Early Cretaceous extension above the mobile salt layer.

\section{Upper Cretaceous}

As evident in Fig. 2, the base Upper Cretaceous is most often parallel to the Lower Cretaceous reflections without a clear impedance contrast. It truncates the Lower Cretaceous reflections only on the flank of a salt swell north of the Aller Linament. Near the eastern margin of the Lower Saxony Basin, the Upper Cretaceous reflections show downlap terminations onto the top Lower Cretaceous, as imaged on the E-W transect. The Upper Cretaceous has a thickness of 0.2 to $0.7 \mathrm{~s} \mathrm{TWT}$, and is characterized by moderate reflectivity, with locally slightly lower amplitude than those of the under- and overlying successions. Only in the area south of Hannover, the Upper Cretaceous is partially missing.

Depositional thickening of the Upper Cretaceous succession usually takes place in salt rim synclines. The most striking thickening occurs adjacent to two major salt cored anticlines developed at the Aller Lineament (Fig. 9). The base Tertiary unconformity clearly truncates the Upper Cretaceous above the crests of these anticlines. The Upper Cretaceous succession thins depositionally towards the salt-cored anticlines, whereas steep faults occur at the northern flank of the anticlines (Fig. 9).

A major reverse fault is present in the western part of the E-W transect adjacent to a salt diapir (Fig. 4). On the opposite side of this diapir a rim syncline shows intra-Upper Cretaceous onlaps of reflections towards its outer margin (Fig. 4). Low angle discontinuities interpreted as thrust planes, contribute to the structural complexity of the Upper Cretaceous succession which depositionally thickens in the footwall of a representative thrust (Fig. 8).

\section{Tertiary}

The base Tertiary usually corresponds to a well-pronounced single or double reflection traceable over long distances of the investigated transects. As visible in the overview Fig. 2, it locally appears as an unconformity truncating the Upper Cretaceous reflections, although more often it is practically parallel to the underlying succession. The Tertiary displays variable, but mostly good, reflectivity and variable thickness ranging between 0 and $1.3 \mathrm{~s}$ TWT south of Hannover and at the western margin of the Pompeckj Block, respectively. The Tertiary is increasingly eroded towards the SW margin of the CEBS and finally disappears just south of the Aller Lineament. Thickness variations of the Tertiary above salt diapirs are probably related to Cenozoic halokinesis. On the E-W transect of Fig. 2, there are three large diapirs characterized by a thinned Tertiary above their crest. Above two other diapirs, the base Tertiary is involved in the structuration and affected by normal faults.

\section{Tectonic interpretation}

The quality of the seismic data mostly prevents conclusive observations of tectonic structures below the Zechstein evaporite layer. Despite the strongly deformed Upper Permian salt and Mesozoic and Cenozoic sequences, the uniform thickness of Buntsandstein and Muschelkalk sediments along the investigated transects implies a period of tectonic quiescence during the Early and Middle Triassic. The seismic data poorly image the internal stratigraphy of Buntsandstein which, in the Netherlands and NW Germany, consists of a 


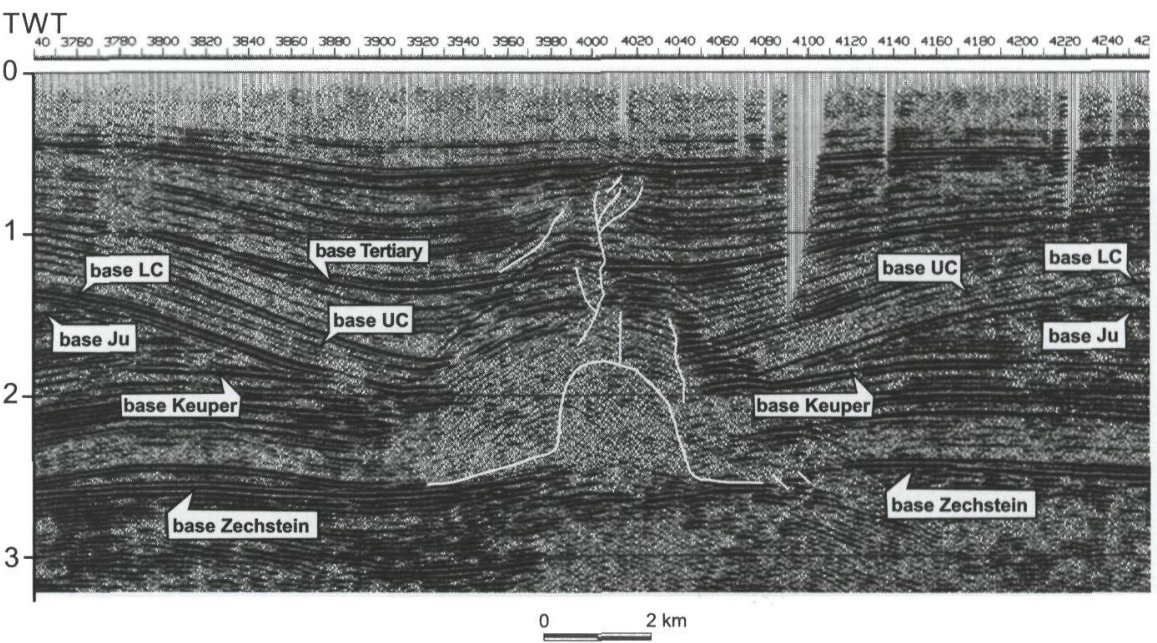

Fig. 6. Detail of the WNW-ESE seismic transect across the Pompeckj Block, illustrating the base Cretaceous unconformity related to the Late Jurassic uplift. Note the deep truncation of the unconformity reaching the Keuper. The central salt diapir was rising during the Late Cretaceous, but collapsed in the Tertiary. Normal faults affecting the Upper Cretaceous to Triassic layers developed above the diapir, but their activity mostly ceased in the Cenozoic. LC - Lower Cretaceous; Ju - Jurassic; Mu - Muschelkalk.

WNW

ESE

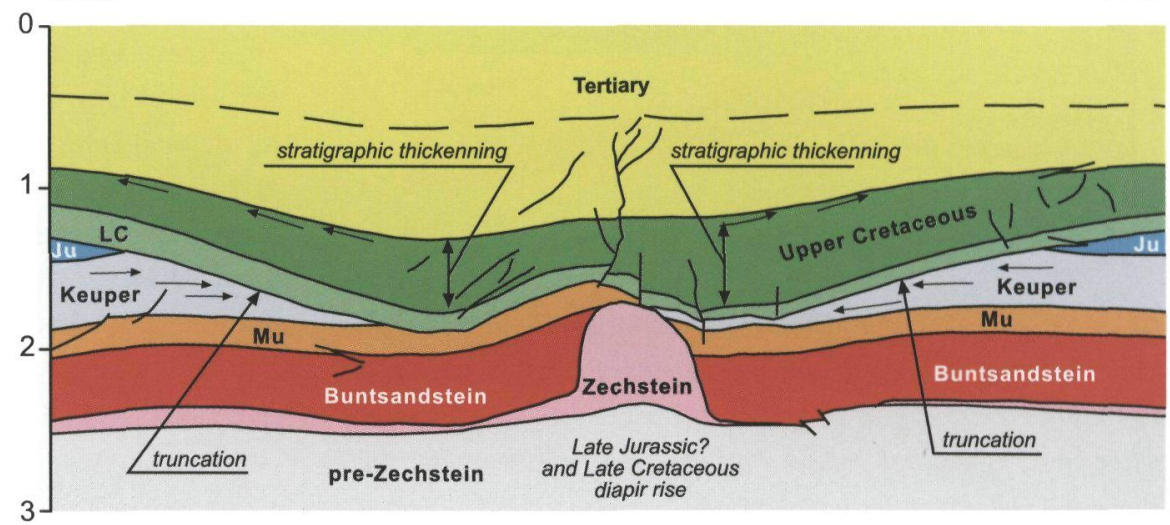

number of sedimentary sequences separated by low-angle unconformities (e.g. Röhling, 1991; Geluk \& Röhling, 1997). These unconformities, including the most important Hardegsen unconformity, are not observed on the studied seismic lines because of insufficient resolution of the data and/or due to the fact that the unconformities may become less prominent towards the centre of the North German Basin. The latter possibility is suggested by their absence also on other seismic profiles from the central part of the basin (Kossow \& Krawczyk, 2002). Thus, the oldest tectonic phase clearly imaged by the interpreted seismic profiles is of Late Triassic age.

\section{Keuper extension and initiation of salt movements}

The Late Triassic structuration is generally related to syndepositional salt mobility. The thickness of the Keuper increases in the rim synclines associated with some of the salt diapirs (Figs 3, 4). Furthermore, normal faults at pre-Zechstein levels probably control the position of the salt diapirs above (Fig. 3). On the WSW-ENE oriented cross-section, such normal faults show consistent dip towards the WSW. The Late Triassic tectonic movements resulted not only in differential subsidence (Scheck \& Bayer, 1999; Maystrenko et al., 2005) but also in localized salt-induced uplift causing truncation of Keuper sediments down to the underlying Muschelkalk (e.g. Figs 5, 9).

\section{Jurassic subsidence}

The Jurassic was mostly a period of accelerated subsidence, particularly evident in the area of the Lower Saxony Basin. Farther north, however, within the Pompeckj Block, the Jurassic also locally attains a considerable thickness. Significant Jurassic salt mobility is minor along the investigated transects, although depositional thickening near salt structures along the $\mathrm{E}-\mathrm{W}$ transect indicate that some salt movement did occur.

\section{Late Jurassic uplift and Early Cretaceous differential subsidence}

A base Cretaceous regional unconformity is visible along the full length of both transects. The amount of erosion varies along the investigated lines and seems to be the key factor responsible for the thickness variations of the Jurassic. Within the Lower Saxony Basin the erosion was not deep enough to remove the thick Jurassic strata. Farther north, within the Pompeckj Block, the unconformity locally truncates down to the Keuper or even Muschelkalk (Fig. 6). The stratigraphic relationships in the Lower Saxony Basin (Betz et al., 1987) seem to imply that the regional unconformity referred to in this paper as that of the base Cretaceous can at least locally represent the base of uppermost Jurassic (Kimmeridgian, 

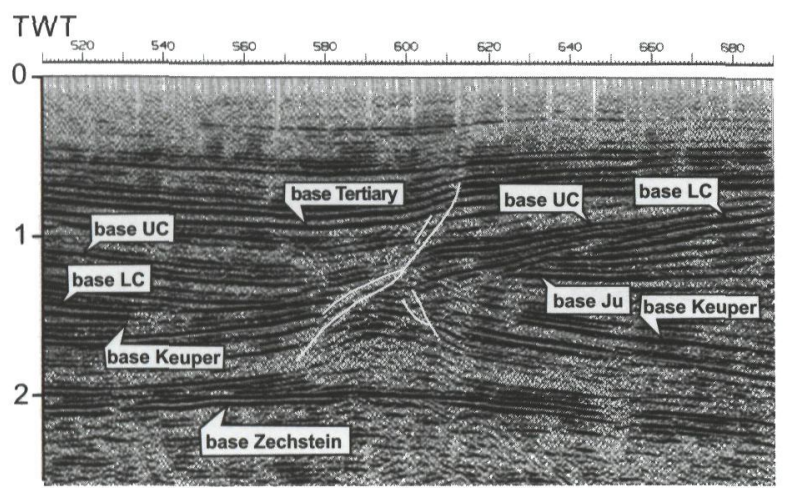

$2 \mathrm{~km}$

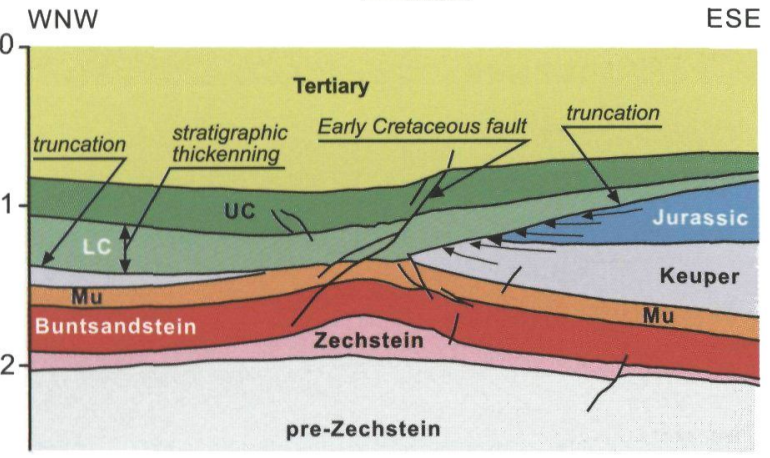

Fig. 7. Close-up of the WNW-ESE seismic transect across the eastern part of the Pompeckj Block illustrating a moderate angle normal fault active from Early Cretaceous to Cenozoic. The erosional base Cretaceous unconformity is also well imaged. Note the undeformed base Zechstein. LC - Lower Cretaceous; Mu - Muschelkalk.

Tithonian). However, the borehole data of Baldschuhn et al. (2001), used for calibration of the studied transects, do not allow the verification of this suggestion. A characteristic feature of the base Cretaceous unconformity is the considerable variation in the amount of erosion over relatively short distances as a result of salt mobility. In most places, the relationship between the present-day salt structures and the amount of erosion is obvious (Fig. 6). In some cases, where this relation is not so clear, the salt may have migrated out of the studied sections (Fig. 2). Interestingly, besides the varying amount of erosion resulting from salt mobility, there are no clear seismic-scale structures, whose origin can be related to the Late Jurassic uplift. This suggests that a broad, regional uplift caused the pre-Cretaceous unconformity.

The Early Cretaceous was a period of limited subsidence in most of the study area with only a modest thickness of Lower Cretaceous sediments. Only in the Lower Saxony Basin near Hannover, a thick Lower Cretaceous sequence indicates localized accelerated subsidence in that area.

\section{Late Cretaceous to Early Tertiary inversion}

The effects of the Late Cretaceous to Early Paleogene inversion are widespread throughout both investigated transects. However, the N-S oriented section reveals the most prominent results of intense inversion tectonics. A significant uplift of the pre-Permian basement south of Hannover results from thick-skinned deformation, involving the basement and its sedimentary cover (Fig. 2), with a maximum uplift at the base Zechstein level of nearly $3000 \mathrm{~m}$. The geometry of the resultant large anticlinal structure apparently influences the spacing of fault zones which cross-cut sediments down to the preZechstein strata. Sediments are predominantly faulted above the upper hinge of the fold (Fig. 2) and within the syncline located farther to the south (Fig. 10).

North of Hannover, the effects of the compressional deformation are obviously decoupled along the layer of Zechstein evaporites. The base Zechstein is remarkably flat, whereas the deformation concentrates in the thick cover of the Mesozoic sediments. The most prominent inversion structure is represented by the Aller Lineament, comprising two overturned anticlines cored by salt (Fig. 9). The adjoining synclines display features of Late Cretaceous syn-sedimentary growth controlled by ongoing deformation and/or halokinesis, which terminated at the turn of Cretaceous and Tertiary (Fig. 9). South of the lineament, the axial part of the Lower Saxony Basin is clearly inverted with a thick sequence of Lower Cretaceous sediments uplifted in a broad arch. The last phase of inversion seems to
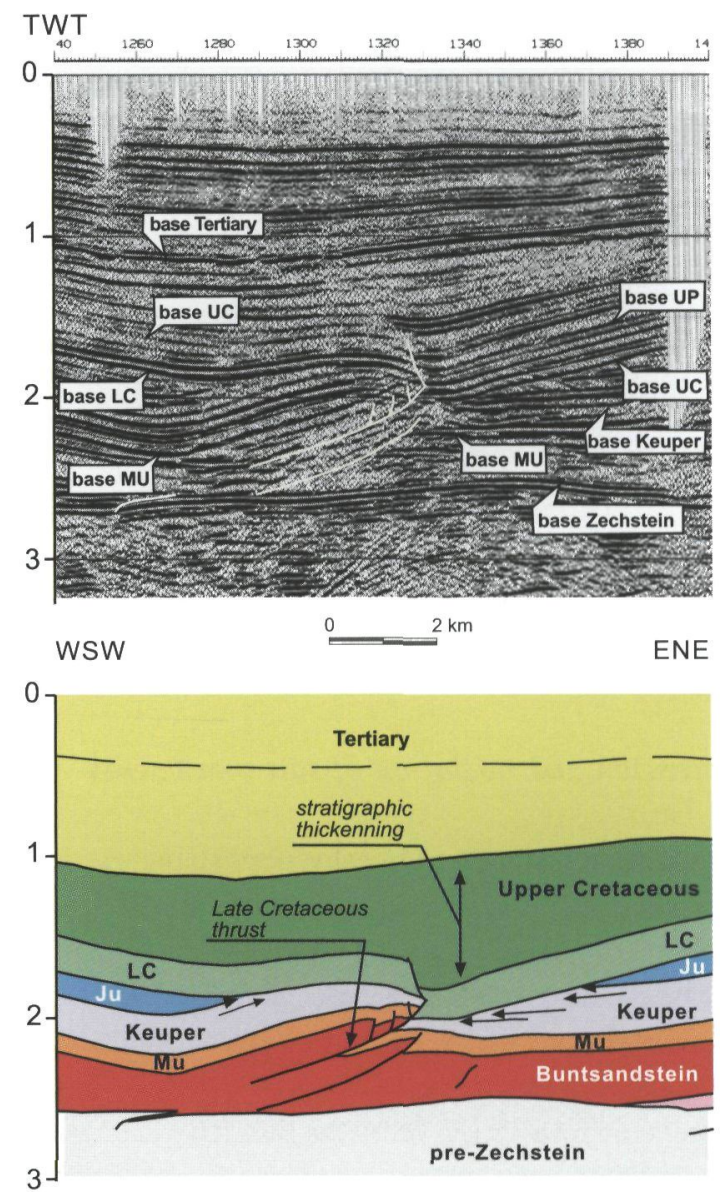

Fig. 8. Close-up of the WSW-ENE seismic transect across the SW part of the Pompeckj Block showing Late Cretaceous thrust decoupled along the salt layer. LC - Lower Cretaceous; Ju - Jurassic; Mu - Muschelkalk. 

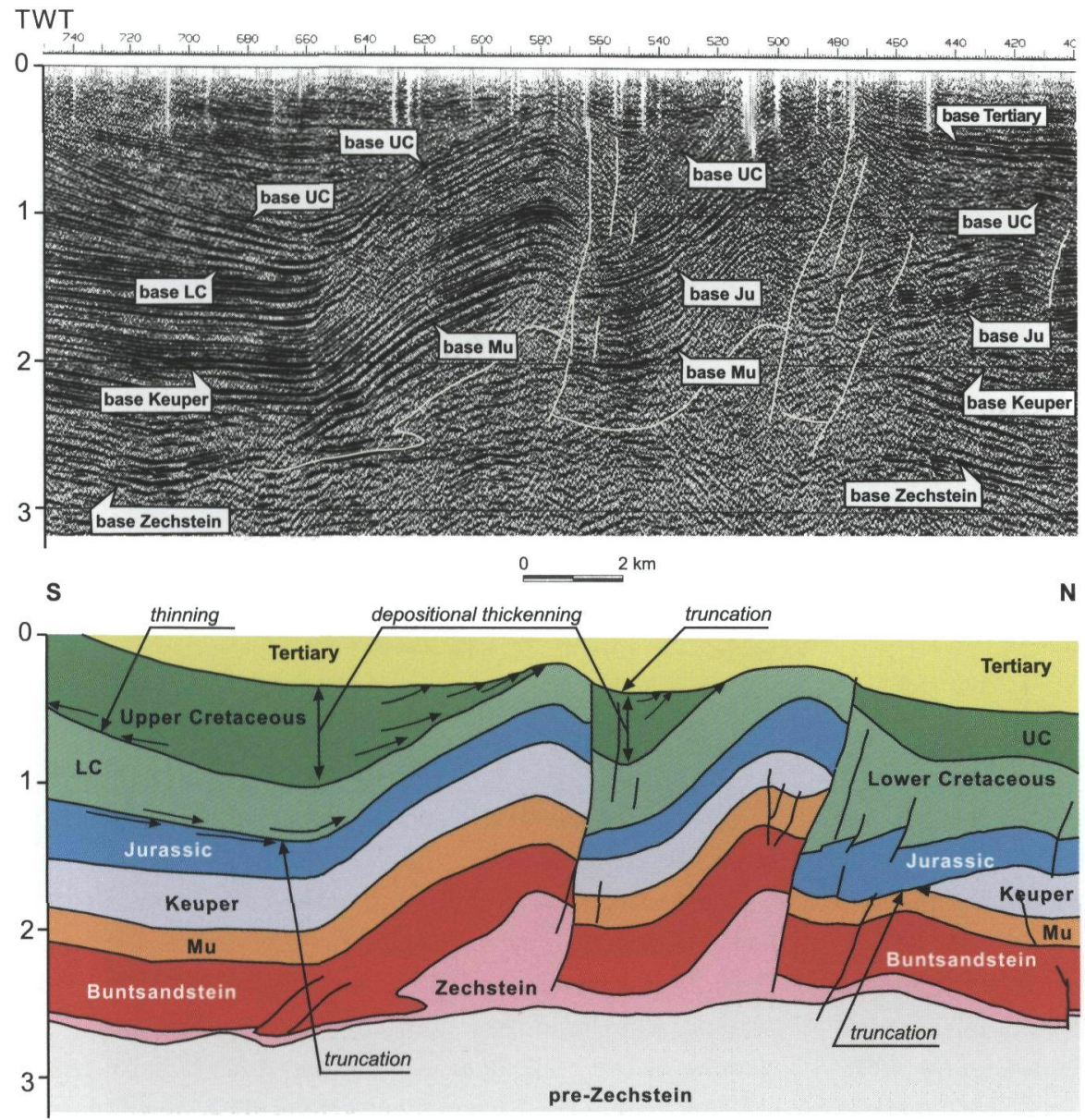

Fig. 9. Detail of the NNE-SSW seismic transect across the Aller Lineament. Here, Late Cretaceous inversion resulted in folding of the salt cover with two anticlines cored by salt. Both anticlines are cut at their northern flank by subvertical reverse faults. The thinning of the Upper Cretaceous successions in the flanking synclines constrains the age of deformation. UP - Upper Cretaceous; LC Lower Cretaceous; Mu - Muschelkalk.

have taken place in the earliest Paleogene as the base Tertiary, unconformably overlying the Aller Lineament, is slightly deformed. Although this effect can be also attributed to Early Paleogene salt diapirism, an Early Tertiary phase of compressive deformation is clearly documented by the reverse fault at the northern margin of the Lower Saxony Basin (Fig. 4). This fault offsets the base Tertiary due to S-directed thrusting, probably oblique to the plane of the section.

The Late Cretaceous compressional deformation induced further salt movement as documented by the thinning of the Upper Cretaceous above a number of salt diapirs (Fig. 2). Furthermore, several thrusts of apparent ENE-ward polarity at base Zechstein level can be tentatively attributed to the Late Cretaceous basin inversion on the E-W transect. However, as these thrusts occur at the Rotliegend/Zechstein interface (Fig. 2), the timing of their growth cannot be unequivocally verified. Nevertheless, one prominent, apparently ENE-vergent thrust occurring within the Mesozoic strata clearly reveals the Late Cretaceous development (Fig. 8). In the E-W oriented transect, the Late Cretaceous syn-sedimentary W-dipping normal fault (Fig. 7) points to W-E oriented extension simultaneous with the development of compressional structures of northward polarity.

Some evidence for the Late Cretaceous stress pattern is provided by the geometry of newly formed conjugate fault systems. The faults intersect along a subhorizonzal axis of approximately E-W orientation perpendicular to the N-S transect (Fig. 2). Since both faults are characterized by reverse throws, their geometry implies a subhorizontal N-S orientation of maximum principal stress $\sigma_{1}$ and a subvertical attitude of $\sigma_{3}$.

\section{Tertiary subsidence}

The inversion of the investigated part of the CEBS was followed by subsidence during the Tertiary. This is documented by a significant cover of Cenozoic sediments which attains the greatest thickness in the areas of the Pompeckj Block and in the western part of the Lower Saxony Basin (Fig. 2). In a few cases, seismic data provide evidence for Cenozoic growth of salt diapirs contemporaneous with overall subsidence (Figs 2, 5). At several locations, the Cenozoic collapse of salt structures is shown by a local downward curvature of the base Tertiary (Figs $4,6)$. The withdrawal of salt is locally associated with normal faulting of the Tertiary succession (Figs 4, 6).

\section{Discussion}

Despite of a moderate resolution in the seismic reflection data and a limited number of the studied profiles, their interpretation allows to distinguish a sequence of different tectonic 


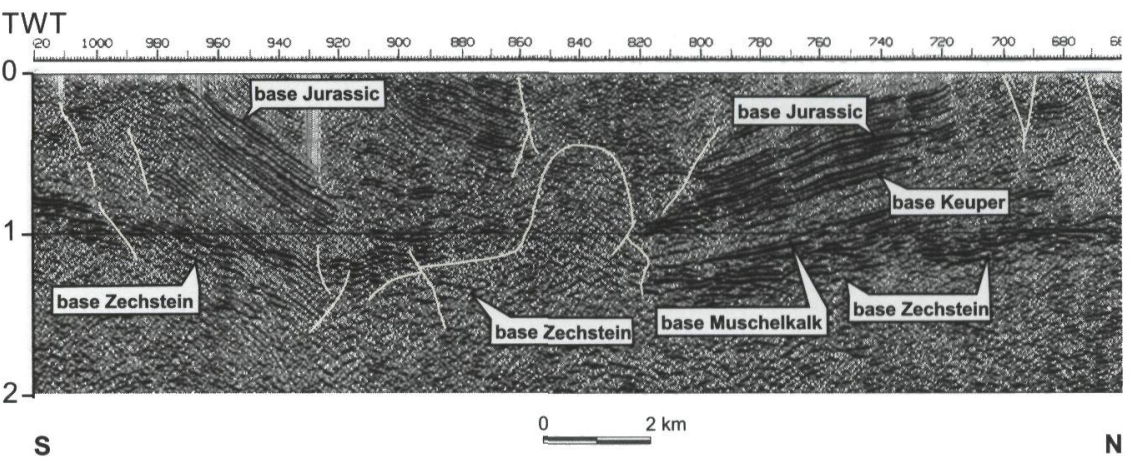

Fig. 10. Close-up of the NNE-SSW seismic transect across the South Hannover Hills showing a syncline related to thick-skinned folding as a result of Late Cretaceous inversion tectonics. LC - Lower Cretaceous; Mu - Muschelkalk.

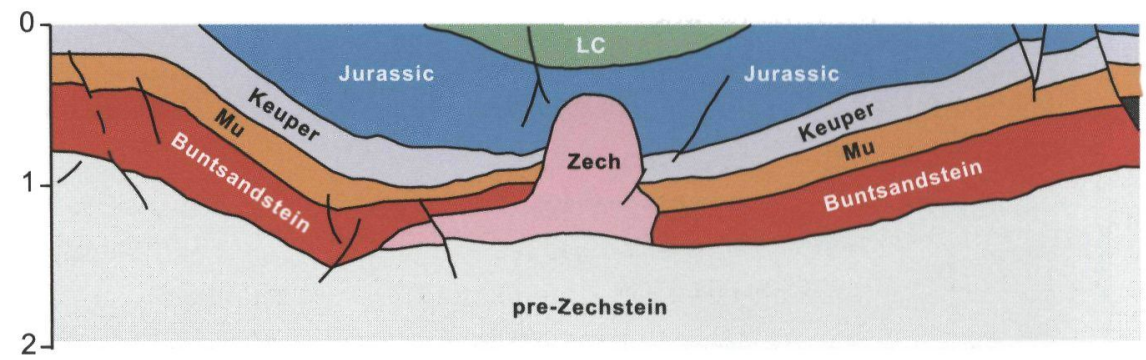

regimes that account for successive deformations in the investigated part of the CEBS. Our results indicate that salt mobilisation started during deposition of the Keuper, was induced tectonically and took place in an extensional setting. Normal faulting and differential subsidence can be interpreted as a shallow crustal expression of approximately E-W directed lithosperic extension. The presence of consistently WSWdipping faults reaching downward into the pre-Zechstein strata suggests that localization of deformation in the salt cover as well as salt mobilization were related to discontinuities in the sub-salt sequences. Above the salt, the localized uplift was mostly related to halokinesis.

The Late Triassic tectonic event corresponds to a period of approximately E-W directed extension in NW Europe (Betz et al., 1987; Ziegler, 1990; Walter, 1992). The vertical orientation of $\sigma_{1}$ and $E-W$ orientation of $\sigma_{3}$ (Betz et al., 1987) may account for the actually observed pattern of normal faults. The most prominent structures produced in NW Europe by this tectonic regime are represented by several NNE-SSW oriented elongated troughs and grabens like the Glückstadt Graben, Emsland Trough and Wesser Depression in northern Germany as well as a number of similarly oriented troughs on the NW European shelf (Best \& Kockel, 1983; Clausen \& Korstgard, 1993; Sundsbo \& Megson, 1993; Baldschuhn et al., 2001; Scheck et al., 2003b). Traces of this Late Triassic tectonic event are described in terms of syn-depositional normal faulting combined with salt mobilization and high amounts of calculated tectonic subsidence (Scheck-Wenderoth \& Lamarche, 2005).

The Widespread Jurassic subsidence throughout the study area may have resulted either from an overall extension or from thermal subsidence and certainly was supported by the global rise in sea level. The lack of seismic-scale structures related to this event leaves this alternative unsolved. Irrespective of the prevailing tectonic regime, the deposition of Jurassic sediments was only accompanied by minor effects of coeval salt movements.

The transition from subsidence to the Late Jurassic uplift is not recorded by any concomitant seismic-scale structures. Thus, after having subsided en bloc during the Early-Middle Jurassic, the basin was uplifted due to a large-scale upwarping of the basin floor. At the same time a global fall in sea level took place. This sequence of events is in accord with the regional extent of the base Cretaceous unconformity recorded along the full length of the studied transects. A characteristic feature of the Late Jurassic uplift is an increasingly deeper erosional truncation of the pre-Cretaceous strata towards the north and east. Several previous interpretations postulated differential subsidence during the Early-Middle Jurassic (e.g. Kockel, 2002). Our seismic data suggest a similar subsidence history in the Lower Saxony Basin and the Pompeckj Block prior to the Late Jurassic uplift. The evolutionary differences between these two units were initiated by the deeper erosion of the Pompeckj Block in the latest Jurassic and, then, increased in the Early Cretaceous due to subsidence of the Lower Saxony Basin. Furthermore, a highly variable level of truncation in the area of the Pompeckj block clearly suggests an important role of contemporaneous salt tectonics. The latter provides an additional argument in favour of tectonically induced erosion and against the correlation of this event with the eustatic change of sea level alone as postulated by Kockel (2002). This line of reasoning is strengthened by significant extent and scale of the Mid- to Late Jurassic uplift reported from the neighbouring areas of the western Baltic Sea (Hansen et al., 2003), the North German Basin (e.g. Kossow \& Krawczyk, 2002) and SW Poland (Karnkowski, 1999).

During the Early to Middle Jurassic, the area of the North Sea was a domain of mild extension and thermal subsidence 
(Doré et al., 1999), followed by thermal doming (e.g. Underhill \& Partington, 1993). Although, the nature, magnitude and significance of the Mid-Jurassic North Sea dome remain a matter of debate (Doré et al., 1999), the investigated part of the CEBS experienced a distinct development, characterized by subsidence and E-W extension. Furthermore, in the Late Jurassic north Germany was subjected to overall uplift and erosion, whereas the most intense phase of subsidence took place in the North Sea area (e.g. Badley et al., 1988; Rattey \& Howard, 1993). This apparent paradox can be tentatively explained by an initial thermal doming in the axial zone of the future North Sea rift (Middle Jurassic) and subsequent outward migration of the rift shoulder after the commencement of the rifting (in the Late Jurassic).

No considerable subsidence was resumed in Early Cretaceous times on the Pompeckj Block. This period was characterized by minor salt mobility and high-rate subsidence localized along the Lower Saxony Basin. All these features are in agreement with the Early Cretaceous dextral transtensional regime previously postulated for the CEBS (Betz et al., 1987; Ziegler, 1990). Hence, the deeply subsided part of the Lower Saxony Basin can represent one of the en-echelon pull-apart basins formed along the SW margin of the CEBS due to transtensional deformation along the Elbe Fault System (EFS). The transtensional concept is supported by seismic data showing latest Jurassic-Early Cretaceous flower structures in other NW-SE oriented sub-basins, like those of Lower Saxony Basin (Betz et al., 1987), of the Subhercynian Basin (0tto, 2003), the SE North Sea and the West Netherlands (Nalpas et al., 1995).

The seismic data show that the presence of evaporites enables decoupling of compressional deformation across the basin. This is illustrated by the inversion structures north of Hannover, which developed above a more or less flat base Zechstein. At the same time, in the area south of Hannover, with no Zechstein salt, the entire sedimentary fill of the basin is deformed together with the pre-Zechstein basement. The significant uplift of the basin floor in the latter area was probably also connected with the presence of a crustal weakness zone which localized the deformation within the basement. This zone, corresponding to the EFS, defined the margin of the North German Basin and prevented basement deformation in the interior of the basin. In contrast, the compressive stress transmitted to the salt cover of the basin in the north, was sufficient to promote the development of decoupled inversion structures and widespread salt mobility. Similarly, the reactivation of pre-existing WNW-ESE to NW-SE striking faults was earlier reported from the Broad Fourteens Basin (de Lugt et al., 2003), the Lower Saxony Basin (Betz et al., 1987) and the Subhercynian Basin (Schwab, 1985; Otto, 2003), all being arranged along the SW margin of the CEBS.

The Late Cretaceous to Early Paleogene compression was, most probably, induced by early phases of the Alpine collision along the southern margin of the European plate (e.g. Ziegler et al., 1990; Ziegler et al., 1995 and references therein). The subhorizontal NNW-SSE orientation of the maximum principal stress $\sigma_{1}$ in the Lower Saxony Basin (Betz et al., 1987) and the $\mathrm{N}-\mathrm{S}$ to NNE-SSW attitude of $\sigma_{1}$ in the East German Basin (Scheck \& Bayer, 1999) is consistent with our data, indicating an approximately $\mathrm{N}$-S-directed horizontal compression.

The resumed Tertiary subsidence was accompanied by salt tectonics manifested by diapir growth or collapse. The only normal faults observed, seem to be related to the withdrawal of salt. There are virtually no structures that can be attributed to ongoing extension. Consequently, the subsidence must have been caused by another mechanism than upper crustal extension, such as, e.g. thermal sagging postulated for the adjacent North Sea (e.g. Ziegler, 1990).

The studied seismic transects corroborate the outcomes of geomechanical models (Hecht et al., 2003), indicating relaxation of the horizontal stresses in a long-lived weakness zone at the SW margin of the CEBS. The presence of persistent weak zones in the evolution of sedimentary basins was recently suggested by several modelling studies (Hansen \& Nielsen, 2003; van Wees \& Beckman, 2000) on the basis of backstripping and subsidence modelling to explain the repeated localization deformation during basin histories. The observed sequence of tectonic events well corresponds to the evolution of the adjacent NE German Basin, as modelled by Scheck \& Bayer (1999), despite the fact that a relatively narrower time span is documented in the present work. Nevertheless, the recognized significance of the Late Jurassic uplift and erosion may alter the subsidence estimations for the NE German Basin in the Mesozoic era.

\section{Conclusions}

The tectonic evolution in the southern part of the CEBS was controlled by the interplay between far-field horizontal stresses, local salt mobilisation and vertical movements of the basin floor. The latter resulted in overall subsidence or uplift of the basin, being only weakly expressed in seismic-scale deformation. Salt mobility was induced by horizontal stresses as well as by accelerated uplift or subsidence of the basin.

Compressional or extensional deformation related to the far-field stresses are decoupled along the layer of evaporites. Consequently, crustal stretching or shortening can result in shallow structuration that is not related to deformation below the salt. Nevertheless, in the case of a thin salt layer and/or strong strain localization in the basement rocks, deformation of the latter is transmitted into the overlying sediments.

The overall subsidence and inversion of the investigated area was considerably influenced by the presence of a zone of crustal weakness (EFS) along the SW margin of the CEBS. This zone allowed the strain localization to occur in the basin floor due to a favourable oriented far field stress and, thus, enhanced the strain decoupling in the interior of the basin system. 


\section{Acknowledgements}

We thank the WEG (Wirtschaftsverband Erdöl- und Erdgasgewinnung e.V.) and DGMK (Deutsche Wissenschaftliche Gesellschaft für Erdöl, Erdgas und Kohle e.V.) for the permission to use and publish the seismic sections. This work was financially supported by the German Science Foundation in the frame of priority programme 'Sedimentary Basin Dynamics' (DFG SPP1135). Two anonymous reviewers provided helpful and constructive critics and thus helped to improve the quality of this paper. This is publication GEOTECH-127 of the programme GEOTECHNOLOGIEN of BMBF and DFG.

\section{References}

Baldschuhn, R., Binot, F., Fleig, S. \& Kockel, F. (eds), 2001. Geotektonischer Atlas von Nordwest-Deutschland und dem deutschen Nordsee-Sektor Strukturen, Struckurenwicklung, Paläogeographie. Geologisches Jahrbuch A 153: 1-88, 3 CD ROM.

Badley, M.E., Price, J.D., Rambech Dahl, C. \& Agdestein, T., 1988. The structural evolution of the northern Viking Graben and its bearing upon extensional modes of basin formation. Journal of the Geological Society, London 145: 455-472.

Best, G. \& Kockel, F., 1983. Geological history of the southern Horn Graben. Geologie en Mijnbouw 62: 25-33.

Betz, D., Führer, F. \& Plein, E., 1987. Evolution of the Lower Saxony Basin. Tectonophysics 137: 127-170.

Clausen, O.R. \& Korstgard, J.A., 1983. Faults and faulting in the Horn Graben Area, Danish North Sea. First Break 11(4): 127-143.

De Lugt, I.R., van Wees, J.D. \& Wong, Th.E., 2003. The tectonic evolution of the southern Dutch North Sea during the Paleogene: basin inversion in distinct pulses. Tectonophysics 373: 141-159.

Doré, A.G., Lundin, E.R., Jensen, L.N., Birkeland, Ø., Eliassen, P.E. \& Fichler, C., 1999. Principal tectonic events in the evolution of the northwest European Atlantic margin. In: Fleet, A.J. \& Boldy, S.A.R. (eds): Petroleum Geology of Northwest Europe: Proceedings of the 5th Conference. Geological Society of London (London): 41-61.

Geluk, M.C., Plomp, A. \& Van Doorn, Th.H.M., 1996. Development of the Permo-Triassic succession in the basin fringe area, southern Netherlands. In: Rondeel, H.E., Batjes, D.A.J. \& Nieuwhuijs W.H. (eds): Geology of gas and oil under the Netherlands, Kluwer, Dordrecht: 57-78.

Geluk, M.C. \& Röhling, H.-G., 1997. High-resolution sequence stratigraphy of the Lower Triassic 'Buntsandstein' in the Netherlands and northwestern Germany. Geologie en Mijnbouw 76: 227-246.

Hansen, D.L. \& Nielsen, S.B., 2003. Why rifts invert in compression? Tectonophysics 373: 5-24.

Hansen, M.B., Deghani, A., Gajewski, D., Hübscher, C., Lykke-Andersen, H., Nørmark, E. \& Reicherter, K., 2003. Neotectonics in the western Baltic Sea (NeoBaltic). Terra Nostra 2003/07. In: Littke, R., Bayer, U. \& Gajewski, D. (eds): Dynamics of Sedimentary Systems under varying Stress Conditions by Example of the Central European Basin System, Selbstverag der AlfredWegener-Stiftung, Berlin: 21-24.
Hecht, C.A., Lempp, C. \& Scheck, M., 2003. Geomechanical model for the postVariscan evolution of the Permocarboniferous-Mesozoic basins in Northeast Germany. Tectonophysics 373: 125-139.

Jaritz, W., 1987. The origin and development of salt structures in northwest Germany. In: Lerche, I. \& 0'Brien, J.J. (eds): Dynamical geology of salt and related structures. Orlando, Academic Press: 480-493.

Karnkowski, P.H., 1999. Origin and evolution of the Polish Rotliegend Basin. Polish Geological Institute Special Papers 3: 1-93.

Kockel, F., 2002. Rifting processes in NW-Germany and the German North Sea Sector. Netherlands Journal of Geosciences / Geologie en Mijnbouw 81(2): 149-158.

Kockel, F., 2003. Inversion structures in Central Europe - Expressions and reasons, an open discussion. Netherlands Journal of Geosciences / Geologie en Mijnbouw 82(4): 367-382.

Kossow, D. \& Krawczyk, C.M., 2002. Structure and quantification of processes controlling the evolution of the inverted NE-German Basin. Marine and Petroleum Geology 19: 601-618.

Nalpas, T., Douaran, S.L., Brun, J.-P., Unternehr, P. \& Richert, J.-P., 1995. Inversion of the Broad Fourteens Basin (Netherlands offshore), a small-scale model investigation. Sedimentary Geology 95: 237-250.

Maystrenko, Y., Bayer, U. \& Scheck-Wenderoth, M., 2005. The Glückstadt Graben, a sedimentary record between the North and Baltic Sea in north Central Europe. Tectonophysics 397 (1-2): 113-126.

Otto, V., 2003. Inversion-related features along the southeastern margin of the North German Basin (Elbe Fault System). Tectonophysics 373: 107-123.

Rattey, R.P. \& Hayward, A.P., 1993. Sequence stratigraphy of a failed rift system: the Middle Jurassic to Early Cretaceous basin evolution of the Central and Northern North Sea. In: Parker, J.R. (ed.): Petroleum Geology of Northwest Europe: Proceedings of the 4th Conference. Geological Society of London (London): 215-250.

Röhling, H.-G., 1991. A lithostratigraphic subdivision of the Early Triassic in the Northwest German Lowlands and the German sector of the North Sea, based on Gamma Ray and sonic Logs. Geologisches Jahrbuch 119: 3-23.

Scheck, M. \& Bayer, U., 1999. Evolution of the Northeast German Basin inferences from a 3D structural model and subsidence analysis. Tectonophysics 313: 145-169.

Scheck, M., Bayer, U., Otto, V., Lamarche, J., Banka, D. \& Pharaoh, T., 2002 The Elbe Fault System in North Central Europe - a basement controlled zone of crustal weakness. Tectonophysics 360: 281-299.

Scheck, M., Bayer, U. \& Lewerenz, B., 2003a. Salt redistribution during extension and inversion inferred from 3D backstripping. Tectonophysics 373 55-73.

Scheck, M., Bayer, U. \& Lewerenz, B., 2003b. Salt movements in the Northeast German Basin and its relation to major post-Permian tectonic phases results from $3 \mathrm{D}$ structural modelling, backstripping and reflection seismic data. Tectonophysics 361: 277-299.

Scheck-Wenderoth, M. \& Lamarche, J., 2005. Crustal memory and basin evolution in the Central European Basin System - new insights from a 3D structural model. Tectonophysics 397 (1-2): 143-165.

Schwab, G., 1985. Paläomobilität der Norddeutsch-Polnischen Senke. Berlin, Akadmie der Wissenschaften der DDR, Dissertation B: 196 
Stephenson, R.A., Narkiewicz, M., Dadlez, R., Van Wees, J.-D. \& Andriesses, P.,

2003. Tectonic subsidence modelling of the Polish Basin in the light of new data on structural structure and magnitude of inversion. Sedimentary Geology 156: 59-70.

Sundsbø, G.O. \& Megson, J.B., 1993. Structural styles in the Danish Central Graben. In: Parker, J.R. (ed.): Petroleum Geology of Northwest Europe: Proceedings of the 4th Conference. Geological Society of London (London): 1255-1268.

Underhill, J.R. \& Partington, M.A., 1993. Jurassic thermal doming and deflation in the North Sea: implications of the sequence stratigraphic evidence. In: Parker, J.R. (ed.): Petroleum Geology of Northwest Europe: Proceedings of the 4th Conference. Geological Society of London (London): 337-346.

Van Wees, J.-D. \& Beekman, F., 2000. Lithosphere rheology during intraplate basin extension and inversion - Inferences from automated modelling of four basins in western Europe. Tectonophysics 320: 219-242.

Walter, R., 1992. Geologie von Mitteleuropa. Schweizerbart (Nägele und Obermiller), Stuttgart: 1-561.

Ziegler, P.A., 1990. Geological Atlas of Western and Central Europe 2nd Edition. Shell Internationale Petroleum Mij. BV and Geological Society of London (London): 1-239.

Ziegler, P.A., Cloetingh, S. \& Van Wees, J.-D., 1995. Dynamics of intra-plate compressional deformation: the Alpine foreland and other examples. Tectonophysics 252: 7-59. 